\title{
Developing Nursing and Midwifery Informatics Position Statements: Why Do They Matter for Our Workforce?
}

\author{
Karen BLAKE ${ }^{\mathrm{a}, 1}$, Karen DAY ${ }^{\mathrm{b}}$, Aaron JONES ${ }^{\mathrm{c}}$ and Naomi DOBROFF ${ }^{\mathrm{d}}$

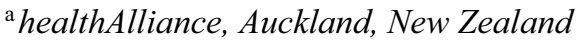 \\ ${ }^{\mathrm{b}}$ School of Population Health, The University of Auckland, Auckland, New Zealand \\ ' Sydney Local Health District, Sydney, Australia \\ ${ }^{\mathrm{d}}$ Monash Health, Melbourne, Australia
}

\begin{abstract}
Nursing and midwifery informatics position statements are important to guide and inform our workforce. Australasian position statements have been developed to establish the place of nursing and midwifery informatics in the health system and progress the development of senior roles.
\end{abstract}

Keywords. Nursing informatics, clinical informatics, position statements, workforce development, nursing, midwifery

\section{Introduction}

Nursing and midwifery informatics is an emerging key component of the professions. It requires a position statement to provide guidance, propose recommendations, educate patients/consumers and their family, inform decision makers, and strengthen the views of nursing and midwifery regarding this emerging component. [1,2]. There are few resources or frameworks to guide the development and implementation of position statements in the health sector.

\section{Nursing and Midwifery Informatics Position Statements}

Although the International Council of Nursing (ICN) has only one nursing informatics position statement the United States of America's Nursing Council has several informatics-related position statements [1]. Instead of position statements in the United Kingdom, the Faculty of Clinical Informatics was established in 2018 to support and enable the contribution of different roles [3]. Australasian nursing and midwifery informaticians are in the process of developing position statements to establish their place in the health system and progress the development of senior roles, as depicted in Table 1. A typical process includes consultation and input from experts and stakeholders

\footnotetext{
${ }^{1}$ Corresponding Author, Karen Blake, healthAlliance, 585 Great South Road, Penrose, Auckland, New Zealand; E-mail: Karen.blake@healthalliance.co.nz.
} 
in the form of workshops, document reviews, and discussions before the statement is published [2].

Table 1. Summary of Australasian nursing/clinical informatics position statements.

\begin{tabular}{|c|c|c|}
\hline Position statement & Summary & Publication \\
\hline $\begin{array}{l}\text { Nursing informatics position } \\
\text { statement, by Health } \\
\text { Informatics Society of } \\
\text { Australia (HISA), Nursing } \\
\text { Informatics Australia (NIA), } \\
\text { and the Australian College of } \\
\text { Nursing } \\
\text { (ACN) }\end{array}$ & $\begin{array}{l}\text { Outlines seven key domains of nursing } \\
\text { informatics to ensure that nursing informatics } \\
\text { specialists are supported in future work. }\end{array}$ & $2017(4)$ \\
\hline $\begin{array}{l}\text { CNIO position statement, by } \\
\text { ACN closed Community of } \\
\text { Practice }\end{array}$ & $\begin{array}{l}\text { Outlines role and value of Chief } \\
\text { Nursing/Midwifery Information Officers } \\
\text { (CNIO/CNMIO), recommending the role as } \\
\text { integral to nursing workforce, development and } \\
\text { endorsement of nursing clinical terminology, } \\
\text { nursing informatics as a specialisation. }\end{array}$ & $\begin{array}{l}\text { Endorsed by ACN } \\
\text { October } 2019, \\
\text { publication } \\
\text { expected in } 2020\end{array}$ \\
\hline $\begin{array}{l}\text { Clinical informatics position } \\
\text { statement, New Zealand, by the } \\
\text { Clinical Informatics Leadership } \\
\text { Network (CiLN) and supported } \\
\text { by Health Informatics New } \\
\text { Zealand (HiNZ) }\end{array}$ & $\begin{array}{l}\text { Interdisciplinary approach, response to the New } \\
\text { Zealand Health and Disability Systems Review } \\
\text { interim report asserting the value that clinical } \\
\text { informaticians bring to the health sector. }\end{array}$ & $\begin{array}{l}\text { Draft in } \\
\text { consultation, } \\
\text { publication } \\
\text { expected in } 2020\end{array}$ \\
\hline
\end{tabular}

\section{Panel Discussion}

The panelists are subject matter experts on nursing and midwifery informatics position statements. The three position statements will be presented, and the processes used to develop these will be outlined, followed by a facilitated discussion with the audience. Aspects of the topic will include (but not be limited to) the importance of advocacy for nursing and midwifery informatics roles, how nurses and midwives use position statements to hold space in clinical informatics, the process of developing position statements and how these can be used across the health sector, the implications of position statements and the body of work that follows publication. We will finish with a call to action for people, organisations and governments

\section{The Panel}

Facilitator (Ms Karen Blake, Head of Clinical Informatics, healthAlliance)

Karen Blake's experience spans over 20 years of midwifery practice in Australia and New Zealand, along informatics, management, education and senior policy roles. Karen is on the board of directors for HiNZ and HL7 New Zealand, and is the Co-Chair of CiLN. She will set the agenda, encourage debate, elicit audience questions and coordinate logistics 
Panellist 1 (Dr Karen Day, Director of Postgraduate Programme in Health Informatics, University of Auckland)

Karen Day's current research is about identifying and building the health informatics workforce, identifying competencies and opportunities for education and practice. She will present on aspects of her workforce research and her role in developing the Clinical Informatics Position Statement for New Zealand.

\section{Panellist 2 (Mr Aaron Jones, CNMIO, Sydney Local Health District)}

Aaron was appointed as the first CNMIO in New South Wales in 2015, and has worked in nursing for over 25 years. He is the co-lead for the ACN Informatics Community of Interest, and is a founding member of the Australian CNMIO collaborative. He will describe the process of establishing the CNMIO collective, and why position statements are important for the nursing informatics workforce.

\section{Panellist 3 (Adjunct Associate Professor Naomi Dobroff, CNMIO, Monash Health)}

Naomi has a Masters degree in Public Health, is a Fellow of ACN, and holds an honorary position at Deakin University. Naomi recently completed five years as Chair of the Victorian Board of the Nursing and Midwifery Board of Australia, and is Chair of the ACN Nursing Informatics Community of Interest. Naomi will discuss the impetus, development and use of the Australian nursing informatics position statement.

Panellist 4 (Dr Jen Bichel-Findlay, Honorary Associate, University of Technology Sydney)

Jen has 20 years' experience in health informatics, and is currently a Director of HISA, Chair of the HISA New South Wales Branch, and is a member of the Certified Health Informatician Australasia Examination Committee, Healthcare Information and Management Systems Society Global Conference Education Committee, and Vice President Special Affairs of International Medical Informatics Association. She will discuss how position statements transform nursing leadership, education and practice

\section{References}

[1] American Nurses Association (ANA). ANA Official Position Statements [7/11/2019]. Available from: https://www.nursingworld.org/practice-policy/nursing-excellence/official-position-statements

[2] McGrail K, Jones K, Akbari A et al. A position statement on population data science. International Journal of Population Data Science. 2018;3(1).

[3] De Lusignan S, Barlow J, Scott PJ. Genesis of a UK Faculty of Clinical Informatics at a time of anticipation for some, and ruby, golden and diamond celebrations for others. Journal of Innovation in Health Informatics. 2018;24(4):344-6.

[4] Australian College of Nursing, Health Informatics Society of Australia and Nursing Informatics Australia. Nursing Informatics Position Statement 2017. Available from: https://www.hisa.org.au/wpcontent/uploads/2017/08/Nursing-Informatics-Position-Statement_06082017.pdf 